\title{
GODIŠNJI OBIČAJI
}

Aleksandra VLATKOVIĆ

Antuna Šoljana 6

10000 Zagreb

\section{UVOD}

U poglavlju o godišnjim običajima na području Krivoga Puta ${ }^{1}$ opisani su običaji božićnog i uskrsnog razdoblja, ophodi s vučjom kožom, te oni vezani uz spomendane Svetoga Jurja, Svetoga Ivana i Svetoga Martina. ${ }^{2}$

Godišnji običaji primorskih Bunjevaca, dijelom su obrađeni u knjizi Rikarda Pavelića, kraćim prikazom pojedinih tema godišnjih običaja. ${ }^{3}$ Ukratko su opisani: spomendan svetog Ivana, poklade, Velika Gospa, te blagoslov kuća na Sveta tri kralja (1973:183). ${ }^{4}$ Novije podatke, prikupljene vlastitim terenskim istraživanjem 2004. godine, donosim u ovom prilogu. ${ }^{5}$

Protok vremena može se promatrati ciklički i linearno. Ciklički kalendar često se povezuje s mitskim vremenom, a linearni s racionalnom koncepcijom svijeta i života. Također, ciklički kalendar može se tumačiti kao rezultat mitskog sukoba načela reda i nereda čija posljedica je kružno izmjenjivanje godišnjih doba. Određene obredne radnje, koje se održavaju na dane crkvenih blagdana, možemo vezati uz cikličko shvaćanje vremena jer se iz njihova značenja iščitava poticanje vječnog obnavljanje prirode, te rodnosti i obilja u predstojećoj godini. (Belaj 1998:100-103) U cikličkom shvaćanju tijeka vremena, ali i u linearnom, blagdani ritmiziraju svakodnevicu. Oni nas na taj način vežu uz prirodu i njezino obnavljanje. Suvremeni čovjek u većini slučajeva živi neovisno o prirodnim mijenama, ali ga blagdani svojim običajima na određen način vraćaju prirodi (Rihtman-Auguštin 1992:13).

Prema definiciji njemačkog etnologa Andreasa C. Bimmera, običaj nije poželjna radnja koja se spontano odvija, već traži određenu pravilnost i ponavljanje, skupinu koja ga izvodi i za koju ta radnja ima značenje; $k$ tome, običaj zahtjeva da je tijek radnje obilježen početkom i krajem, a da je formalni $i$ znakovni jezik poznat skupini koja ga provodi” (Bimmer 1994:375-385; prema Čapo Žmegač 1997:8).

Etnolozi su se u ranijim radovima uglavnom bavili istraživanjem porijekla pojedinih običaja, tragali su za izvornim oblikom običaja, a zanemarivali kontekst običaja u zajednici koju su istraživali. Prekretnicu u tumačenju običaja predstavljaju teze njemačke etnologinje Ingeborg Weber-Kellerman, koja smatra da su

1 U tekstu se pojam „područje Krivoga Puta“ odnosi na sve istražene lokalitete (vidi bilješku broj dva) budući da su mu navedena naselja gravitirala tijekom istraživanog razdoblja. Osim područja Krivoga Puta postoji i istoimeni lokalitet, stoga je u tekstu jasno naznačeno na što se odnosi konkretni podatak.

2 Tema godišnjih običaja Krivopućana, istraživana je u svibnju 2004. i srpnju 2005. godine u mjestima: Veljunu, Rupa, Šojatski Dolac, Mrzli Dol, Lucići, Šolići, Žuljevići, Škopci i Krivi Put. U srpnju 2005. godine kolegica Petra Kelemen provela je dopunska istraživanja teme godišnjih običaja u mjestima Veljun, Mrzli Dol, Lucići, Krivi Put i Senj, te se u radu koristim podacima dobivenim tom prilikom. Tekst je u izmjenjenoj varijanti objavljen u Senjskom zborniku, 32 (2005:317-348).

3 U poglavlju Način života, narodna vjerovanja i običaji (Pavelić 1973: 176-187).

4 Manjkavost ove knjige je činjenica da autor vrlo često ne navodi točne lokalitete na kojima je određena pojava zabilježena. Podatke o pokladama i danu Svetoga Ivana autor temelji na iskazu triju kazivačica od kojih za dvije navodi da su iz Senja, ali ne navodi mjesto njihovog rođenja ili mjesta na koje se njihova kazivanja odnose. Naime, običaji koji su u knjizi zabilježeni, očito se odnose na sela senjskog zaleđa, a ne na Senj, kako nam autor načinom opisivanja sugerira, a takvim poopćavanjima, prisutnim u cijeloj knjizi, gubi se pouzdanost podataka.

5 S obzirom na slabu istraženost ove teme istraživanje se uglavnom temelji na kazivanjima, a kao izvor su poslužile i Upitnice Etnološkog atlasa (UEA) za naselje Krivi Put (Fd 241/1382), pohranjene na Odsjeku za etnologiju i kulturnu antropologiju Filozofskog fakulteta u Zagrebu. 
običaji sredstva komuniciranja koji, s vlastitim pravilima i predlošcima, prenose poruke unutar određene zajednice i izvan nje. I. Weber-Kellerman smatra da je crkveno-kultno nemoguće odvojiti od pučkogobičajnog, te da pri istraživanjima treba promatrati njihovo prožimanje (Weber-Kellermann 1985; prema Čapo Žmegač 1997:17), što, u okviru hrvatske etnologije, konkretnije proučavanja uskrsnih običaja, najcjelovitije primjenjuje Jasna Čapo Žmegač (usp. Čapo Žmegač 1997).

Godišnji su običaji povezani s važnijim crkveno-kalendarskim datumima, ali u svojoj jezgri sadrže nekršćanske elemente koji su tijekom vremena kristijanizirani. Ovakvu usporednost kršćanskih i nekršćanskih elemenata, odnosno vjerovanja, Pjotr G. Bogatirjov naziva "dualizmom vjerovanja” ili "religijsko-magijskim sinkretizmom", te smatra kako ruralno stanovništvo u tom dualizmu ne vidi dva suprotstavljena vjerska sustava, već da se ti sustavi prožimaju i međusobno osnažuju (Bogatirijov 1971:198-199, prema Rihtman-Auguštin 1992:121-122). Kao primjer može se navesti prenošenje nekršćanskih običaja vezanih uz početak agrarne godine na Božić kao početak religijske godine.

Tako je na području Krivoga Puta jednaka pažnja u praksi posvećena odlasku na polnoćku i slavljenju rođenja malog Isusa, početku novog života, kao i paljenju panja badnjaka i unošenju slame, radnjama koje se čine $s$ ciljem poticanja vegetacije u predstojećoj agrarnoj godini. ${ }^{6}$

Sve mijene običaja, u prošlosti i danas, pokazuju kako običaji nisu statične pojave, već se mijenjaju ovisno o gospodarskim, političkim i društvenim prilikama, čime običaj "živi“, dokazuje svoj aktualan značaj i ulogu u životu zajednice (usp. Čapo Žmegač 1997:8-13). Pritom običaji istovremeno sadrže kodove društvenog ponašanja, tragove minulih i znakove sadašnjih vremena (Rihtman-Auguštin 1992: 74, 149).

Slijedeći navedene teorijske postavke, pri tumačenju godišnjih običaja na području Krivoga Puta, u prilogu je, kako će čitatelj zamijetiti, pažnja posvećena istraživanju običaja u kontekstu lokalne zajednice, kako ga je prakticirala u prošlosti, a koja je dijelove običaja, u reduciranom obliku i s mijenama u izvedbi i značenju, održala do danas.

\section{BOŽIĆNI OBIČAJI}

$\mathrm{V}$ eć prilikom prvih razgovora s kazivačima očituje se selektivnost tema i običaja o kojima govore i koje u razgovoru vrijednosno ističu. To su prije svega elementi vezani uz Božićni ciklus: Badnjak, Božić, panj badnjak, iznošenje slame na Svetog Ivana i sijanje pšenice na Sveta tri kralja. ${ }^{7}$

Unutar običaja vezanih uz zimsko razdoblje kao uža cjelina prema važnosti se izdvajaju - božićni običaji. Prema hrvatskom etnologu Milovanu Gavazziju, ti običaji počinju znatno ranije od samog Božića, već krajem studenog, a traju do iza Sveta tri kralja (Gavazzi 1939:5). Tijekom ovog razdoblja traju pripreme za obilježavanje Božića, nakon čega se slama i pšenica, pripremljeni u predbožićnom razdoblju, koriste u određenim radnjama za poticanje agrarnog obilja u predstojećoj godini. Ovo razdoblje vezano je uz zimski solsticij i obilježeno kao početak agrarne godine, te je kao takvo, bilo izazov ljudima koji su slavili "tu prirodnu pojavu, nastojeći da učine neku vrstu bilance, te da uoči budenja prirode na odredeni način osiguraju boljitak u neposrednom budućem razdoblju života” (Rihtman-Auguštin 1992:13). ${ }^{8}$

6 Prema kazivanju Krivopućana.

7 O pojedinim običajima Krivopućani su kazivali na temelju sjećanja iz svoje mladosti, prema onome što su proživjeli ili prema onome što su im pričali stariji ljudi. Takvi podaci odnose se na vrijeme njihova djetinjstva, uglavnom na prvu polovicu 20. stoljeća. Podaci o običajima u kojima su sami sudjelovali, nakon Drugoga svjetskoga rata, odnose se na obilježavanje blagdana tijekom socijalističkoga razdoblja, kao i danas.

8 Možemo postaviti pitanje o začudnosti slavljenja početka agrarne godine usred zime. Hrvatski etnolog Vitomir Belaj govori o tome kako je prihvaćanjem kršćanstva prihvaćen i julijanski kalendar u kojem je početak godine smješten na kraj prosinca. Prije prihvaćanja kršćanstva Slaveni su se služili lunarnim kalendarom, prema kojem je godina počinjala s proljećem i početkom vegetacijskog razdoblja (1998:99). S vremenom je proljetni termin početka godine u 


\subsection{PREDBOŽIĆNI OBIČAJI}

Ta području Krivoga Puta, smatra se da je prvi blagdan u zimskom razdoblju Sveti Nikola (6. 1 prosinca). ${ }^{9} \mathrm{Na}$ taj dan roditelji su (pretežno do polovice 20. stoljeća) darivali djecu lješnjacima, orasima, bombonima, jajima, te ukoliko su imali, jabukom, narančom i novcem. Za Svetoga Nikolu roditelji su djeci darivali cipele, košulju ili hlače. Darove su stavljali u opanke ili šlape i u čizme, ako ih je netko imao, koje su djeca uvečer ostavljala pokraj kreveta. Darove su u Lucićima i Veljunu stavljali i pod jastuk. ${ }^{10}$ Običaj darivanja za Svetoga Nikolu bio je češći: Onde di je bilo (zaposlenih op.a.) iz općine, pa su bili žandari, učitelji su bili, oni to malo dalje gledali. ${ }^{11}$

Blagdanom svete Lucije (13. prosinca), na području Krivoga Puta, započinje razdoblje priprema za Božić. Na taj dan je u posudice sijana pšenica koja bi narasla do Božića. Ovaj običaj vrlo je raširen i do danas. Na Krivome Putu ljudi se sjećaju kako su u vrijeme djetinjstva, u prvoj polovici 20. stoljeća, za Svetu Luciju $^{12}$, ponegdje za svetu Katarinu ${ }^{13}$ i Svetu Barbaru ${ }^{14}$, sijali pšenicu i ječam u nekoliko tanjurića. Svaka posudica sa pšenicom posvećivala se pojedincu, te su pšenicu najčešće sijali u onoliko posuda koliko ima članova obitelji, te se prema rastu pšenice određivala budućnost, odnosno uspjeh u idućoj godini. ${ }^{15}$ Danas se izgubila ta "proricateljska" dimenzija rasta pšenice, već sama pšenica koja se unosi u kuću na neki način garantira ili barem potpomaže uspješnost u predstojećoj kalendarskoj godini. ${ }^{16}$

U Veljunu se (do Drugoga svjetskog rata) pšenica sijala u tri posudice, kao simbolika Svetog Trojstva. ${ }^{17}$ Već izrasla, zelena, pšenica stavljala se na badnji stol oko božićnog kruha, a kasnije pod bor, i tu je stajala do Sveta tri kralja kada se iznosila iz kuće. Nakon iznošenja nije se bacala, već su je davali blagu, miješali u sjeme koje će se na proljeće sijati ili je stavili na gumno (prostor na kojem se vršilo žito, op. a.). ${ }^{18}$ Vjerovalo se da će tako zaštiti blago od ugriza zmije, osigurati pšenici bolji rast, te da će kokoši bolje nesti jaja. ${ }^{19}$

Nakon Drugoga svjetskog rata, kada se velik broj stanovnika iz ovih mjesta počeo trajno naseljavati u Senju, pšenicu su odnosili na tvrđavu Nehaj da je pojedu ptice, a neke obitelji to čine i danas ${ }^{20}$, jer se blagoslov ne smije bacati: Čak ni mrve kruha, od jaja ljuske, to se nije dalo da se istresa u smeće nego se stavljalo u papir i bacalo u vatru. ${ }^{21}$

praslavenskom lunarnom kalendaru zaboravljen, a obredi kojima se obilježavao početak agrarne godine preneseni su na kršćanske blagdane. Dio novogodišnjih poganskih obreda prenesen je na Božić, a oni koji su bili usko povezani s proljetnim buđenjem prirode na Uskrs (ibid: 104, 119-134).

9 Milan Krmpotić Zekonja, Veljun; Ive Krmpotić Pićica, Kuljići, Škopci; Mile Prpić Popić, Popići, Mrzli Dol; Ivan Prpić Kavarica, Lucići; Milka Prpić Markina, Veljun; Tome i Ana Špalj Cucini, Senj - Krivi Put; Zlata Tomljanović Pešina, Lucina; Višnja Novoselnik, Senj.

10 Ivan Prpić Kavarica, Lucići; Milka Prpić Markina, Veljun.

11 Tomo i Ana Špalj Cucini, Krivi Put.

12 Sijanje pšenice za Svetu Luciju potvrđeno je i u Upitnici Etnološkog atlasa, prema kazivanju Milana Krmpotića iz Krivog Puta koji navodi i to da se pšenica povezivala trobojnicom, te da su u nju zaticali svijeću koju bi nakon jela gasili vinom (UEA, IV, 135, Fd 241/478).

13 Mile Krmpotić Zekonja, Veljun.

14 Ivan Prpić Kavarica, Lucići.

15 Da se pšenica najčešće sijala u onoliko tanjurića, koliko je bilo članova u obitelji, potvrdili su kazivači u Veljunu, Krivom Putu, Mrzlom Dolu, Rupi i Šojatskom Dolcu.

16 Zlata Tomljanović Pešina, Lucina; Višnja Novoselnik, Senj; Eleonora Prpić Lejina, Veljun.

17 Milka Prpić Markina, Veljun.

18 Pšenicu s božićnog stola domaćim životinjama su davali u selima Veljunu, Podbilu, Škopcima, Krivome Putu, u sjeme za sijanje su je stavljali u Veljunu i Popićima, te na gumno u Veljunu i Krivome Putu.

19 Podatak da božićna pšenica može utjecati na kokoši da bolje nesu jaja čula sam jedino od Marka Pavelića Mijatine iz Žuljevića.

20 Jadranka Tomljanović, Zagreb/Veljun.

21 Jadranka Tomljanović, iz Senja, živi u Zagrebu, koja se ovog običaja sjeća iz djetinjastva, prema kazivanjima njezine bake iz Veljuna. 
Za razdoblje, od Svete Lucije do Božića, u svim je mjestima na području Krivoga Puta, rašireno vjerovanje o određivanju vremenskih prilika za pojedine mjesece u godini, na temelju vremena tijekom tog dvanaestodnevnog razdoblja. Također, tijekom ovog razdoblja, djevojke su na trinaest papirića, koje su držale u posudi ili ispod jastuka, pisale muška imena. To se prakticira i danas, ali među djecom osnovnoškolskog uzrasta, naročito djevojčicama, u smislu igre i zabave. ${ }^{22}$ Svakodnevno bi eliminirale jedan papirić koji bi, ne pogledavši što na njemu piše, bacale u peć. Naime, vjerovale su da će se udati za dečka čije će ime pisati na papiriću koji ostane zadnji. ${ }^{23}$

\subsection{BADNJAK}

$\int$ i

edan od najvažnijih dana zimskoga razdoblja je Badnjak. Ovaj dan obilježen je pripremama za Božić, između ostalog i pripremom hrane za predstojeće blagdansko razdoblje, pečenjem božićnog kruha, pospremanjem kuće, odabirom i odlaskom po panj badnjak, te drugim sličnim poslovima.

\subsubsection{Panj badnjak}

$\mathrm{U}$ Tvećini mjesta na području Krivoga Puta rano ujutro na Badnjak gazda kuće, najstariji član, odlazio je u šumu, u blizini kuće, po panj badnjak. U Veljunu su po badnjak išla djeca ili mladići. ${ }^{24}$

Prema M. Gavazziju, badnjak u prvoj polovini 20. stoljeća nije bio rasprostranjen u cijeloj Hrvatskoj, već na područjima na kojima je još postojalo otvoreno ognjište. ${ }^{25}$ Badnjak se i na ispitivanom području postupno prestajao unositi s nestankom ognjišta. U Veljunu se panj badnjak unosio u kuću sve do prije Drugoga svjetskog rata, kada se umjesto otvorenih ognjišta počinje koristiti šparet, peć na drva. ${ }^{26}$ Običaj se napušta iz praktičnih razloga jer se badnjak, dugačak i do dva metra, ne može staviti u peć.

Za panj badnjak biralo se bukovo ili jasenovo drvo, jedan do dva metra dugačko i deset do petnaest centimetara široko. Ponekad se gledalo da to drvo bude ravnije ili da ima i malo lišća kako bi godina bila rodnija. ${ }^{27}$

Kad se badnjak nekada unosio u kuću, naslonilo bi ga se pokraj ulaznih vrata kuće, te bi ga se kasnije stavljalo na otvoreno ognjište. Panj badnjak gorio je tijekom cijelog dana, do iza polnoćke, sve dok ne pregori. Tko je prvi primijetio da je drvo prigorilo, taj je dobio prvo tele od krava ili janje ako su ovce bile, odnosno novce od prodaje prvog teleta ili janjeta. ${ }^{28}$ Kada je badnjak pregorio, gazda kuće ili neki drugi član obitelji zalijevao ga je vinom i govorio: Ja tebe napajam vinom, ti men Gospodina Boga mirom. ${ }^{29}$

22 Eleonora Prpić Lejina, Veljun.

23 Jadranka Tomljanović i Zlata Tomljanović Pešina. Jadranka Tomljanović o ovom je gatanju čula od svoje majke, Eleonore Prpić Lejine iz Veljuna.

24 Prema kazivanjima Milana Krmpotića Zekonje, Milana i Milke Prpić Markinih, te Ante Krmpotića Škobca po panj badnjak su odlazila djeca ili mladići. Ipak na većem dijelu područja na kojem je ova tema istraživana uobičajeno je bilo da to obave muškarci ili gazda kuće.

25 M. Gavazzi navodi rasprostranjenost panja badnjaka, ali i razna tumačenja ove pojave - kao vrstu fetiša, zatim upućuje na njegovo solarno ili apotropejsko značenje, kao i na povezanost $s$ demonom vegetacije, te na povezanost $s$ pokojnicima. Isti autor pretpostavlja da badnjak nije praslavenskog porijekla, već da su ga Slaveni preuzeli po dolasku u jugoistočnu Europu, od starosjedioca ili nekog drugog, te mu dali opće južnoslavensko ime badnjak. (1939:12-20; 1978:66).

26 Milka i Milan Prpić Markini, Veljun.

27 Milan Prpić Markin, Veljun.

28 Isti kazivač. Taj je podatak zabilježen za Veljun. U većini slučajeva žene su prve primijetile da je drvo prigorilo jer su uvijek bile u blizini ognjišta, dok su muški bili zaokupljeni drugim stvarima kao slamom te igranjem orasima i lješnjacima.

29 Milan Prpić Markin, Veljun. 
Komad drveta koji nije do kraja izgorio spremao se na tavan, ${ }^{30}$ u gospodarski objekt, štalu, ${ }^{31}$ više grede u kući ${ }^{32}$ ili na rožnjik, odnosno gredu na krovu, ${ }^{33}$ te je tu bio do proljeća kada se prilikom oranja zaorao u prvu brazdu ili se pepeo od badnjaka malo posije tobože po njivi. ${ }^{34}$ Oralo se uglavnom početkom travnja, a sam dan nije bio strogo određen. Najčešće objašnjenje takvoga zaoravanja u prvu brazdu je zaštita usjeva od tuče, krupe, odnosno osiguravanje boljeg uroda u tekućoj godini. U Šojatskom Dolcu badnjak je ostajao u zemlji bez obzira što se u nju sijalo ili sadilo, a ako bi ga netko slučajno iskopao motikom morao ga je: Postaviti gdje je bia i zgrnuo si ga zemljom i tu je on trunuo. ${ }^{35}$ Točni razlozi ostavljanja badnjaka u zemlji su uglavnom nepoznati Krivopućanima koji se tog običaja sjećaju. Za taj postupak, pretpostavlja se da je služio za poboljšanje uroda, ili protiv tuče. ${ }^{36}$

Neki se sjećaju da je užareni komad badnjaka stariji ukućanin, gazda, na Badnjak uvečer nosio oko kuće ponavljajući: Neće kuća izgoriti, ${ }^{37}$ vjerujući da će tim postupkom spriječiti da se kuća zapali. Nadalje, žar badnjaka ljudi su na božićno jutro nosili oko voćaka vjerujući da će se tako poboljšati urod. ${ }^{38}$

\subsubsection{Slama}

Drije badnje večeri u kuću se unosila i slama. Najčešće ju je unosio gazda kuće i stavljao pod stol. ${ }^{39}$ Oso1 ba koja je unosila slamu u kuću tom prilikom je izgovarala, nabrajala: Faljen Isus i Marija, u zdravlju vam doša Bog i porođenje Isusovo, Sveti Stjepan, Sveti Ivan i tako, sve one blagdane u tome nabraja. ${ }^{40}$ Unošenje slame u kuću na Božić povezuje se sa slamom na kojoj je rođen Isus. U većini mjesta na području Krivoga Puta ljudi su slamu stavljali na stol, u oblik križa, a preko toga su stavljali stolnjak. ${ }^{41}$ U Veljunu se slama, koja je bila na stolu i ispod kruha, iza Božića stavljala kokošima u gnijezda, pod nasad, da bi se bolje izlegli pilići. ${ }^{42} \mathrm{Na}$ slamu koja se stavljala ispod stola bacalo se lješnjake i orahe, a djeca su se u njoj igrala. ${ }^{43} \mathrm{U}$ Veljunu su na slamu mogli leći i stariji radi večernje radosti. ${ }^{44}$

Slama se iz kuće iznosila na Ivanje ${ }^{45}$ ili na Stipanje, ${ }^{46}$ a u nekim se selima božićna slama iz kuće izno-

30 Ante Krmpotić Škobac, Škopci.

31 Jure Tomljanović Ban, Šolići.

32 Mirko Prpić Cungo, Krivi Put.

33 Tomo i Ana Špalj Cucini, Krivi Put.

34 Ivan Krmpotić Škobac, Škopci. Sličan podatak pronašla sam u UEA gdje je navedeno da se ostaci panja badnjaka (nije preciznije navedeno je li riječ o ugljenu, pepelu ili nedogorjelim dijelovima panja badnjaka) stavljaju u polje prije nevremena kako bi se spriječila tuča. (UEA, IV, 135, Fd : 241/478).

35 Ivan Krmpotić Šoparin, Veljun.

36 Ivanka Krmpotić Grabarova, Veljun; Ivan Krmpotić Šoparin, Veljun; Mirko Prpić Cungo, Krivi Put.

37 Mile Prpić Popić, Mrzli Dol.

38 Ivan Krmpotić Škobac, Škopci.

39 Prema podacima iz UEA u naselju Krivi Put slamu je u kuću na Badnji dan unosio gospodar kuće ili starija žena, a oni tom prilikom nisu bili dočekivani na poseban način. $S$ tom slamom kasnije bi se igrala djeca. (UEA, IV, 135, Fd 241/478).

$40 \quad$ Ivka Krmpotić Grabarova, Veljun; Ivan Krmpotić Šoparin, Šojatski Dolac.

41 Slama se pod stolnjak nije stavljala u Rupi.

42 Milka Prpić Markina, Veljun.

$43 \mathrm{Na}$ badnju je večer poznata dječja igra dešparanje, u kojoj djeca traže lješnjake i orahe po slami, a zatim pitaju jedni druge "Ceš par ili dešpar?». Ako jedno dijete pogodi da li drugo dijete ima paran ili neparan broj pronađenih plodova u ruci dobiva ih, a ako ne pogodi daje plodove koje ima u ruci.

44 Mara Krmpotić Brndina, Veljun.

$45 \mathrm{Na}$ Svetoga Ivana božićnu slamu su iz kuće iznosili u selima Veljun, Škopci i Popići.

46 Na Svetoga Stjepana božićnu slamu su iz kuće iznosili u selima Veljun i Žuljevići, te u Krivom Putu (UEA, IV, 135, Fd 241/478). 
sila na Sveta tri kralja. ${ }^{47}$ Ujutro, na jedan od tih dana, ljudi su slamu najčešće zaticali za voćke, ${ }^{48}$ ali je i postavljali i odnosili u štalu pod blago ${ }^{49}$ ili iza grede, ${ }^{50}$ miješali sa sijenom i davali blagu ${ }^{51}$ ili stavljali u gnijezdo u kojem će se izleći pilići. ${ }^{52}$ Pritom su vjerovali da će voćke bolje roditi, da ih neće uništiti tuča, da neće grom udariti u voćke ili da će se pilići bolje leći. Zadnjih pedesetak godina, unošenje slame gubi značenje i uglavnom se unosi u kuće, a kao razlog zabilježila sam: Trebate imati obitelj, mladu obitelj di su dječica... al di su stari ljudi jel, sta će vam ona slama, nema se tho uvlačiti, nema nigdje ništa. ${ }^{53}$ Pojedinci i danas donesu malo slame u kuću da se djeca igraju, no već drugi dan slamu iznesu iz kuće. ${ }^{54} \mathrm{Na}$ taj način, održava se dio božićnih običaja, ujedno ih se prenosi na mlađe generacije u drugom kontekstu, u gradu, te s promijenjenim značenjem. Božićna slama, unesena u kuću, za djecu i odrasle danas u gradu znači samo zabavu, bez svijesti o njenom nekadašnjem magijskom značenju.

U Veljunu, Rupi, Šojatskome Dolcu i Krivome Putu, ljudi su uz slamu u kuću, pod stol, unosili jaram i teljuge za volove ili hamove za konja. ${ }^{55}$ Vjerovali su da će volovi bolje orati. ${ }^{56} \mathrm{U}$ Veljunu se, uz jaram i teljuge, koje su bile pod stolom, na stol stavljao i brus s kojim su kasnije babe kravama križale vime u slučaju upale. ${ }^{57}$

\subsubsection{Blagdanski stol}

$\mathrm{T}$ ijekom Badnjaka ljudi su pripremali stol i hranu za badnju večeru, koja je prvi ključni trenutak božićnog obiteljskog okupljanja, ali i za ostale blagdanske dane (Rihtman-Auguštin 1992:93). Ispod stola je bila prostrta slama, ali se ona posipala i po stolu, a preko nje se stavljao bijeli šlingani ${ }^{58}$ stolnjak. Na cijelom području Krivoga Puta svečani stol za Badnjak spremao se na karakterističan način: na sredinu stola postavljao se božićni kruh koji se jeo tek na Božić ili Stipanje..$^{59}$ Danas se Krivopućani više ne sjećaju razloga ovoj zabrani, kao ni eventualnih posljedica u slučaju njenog kršenja. Na kruh ili pokraj njega stavljali su jednu ili tri svijeće u čašu napunjenu pšenicom, žitom ili ječmom na koju su stavljali nekoliko režnjića ili čitavu glavicu bijelog luka. Tko je imao jabuku, stavio ju je na stol pokraj kruha. Na stol, oko kruha, slagane su posudice s pšenicom posijanom na Svetu Luciju. Kruh se stavljao na slamu, izravno ili preko stolnjaka i bio je omotan bršljanom kojeg su brali u Senju.$^{60}$ Bršljan su iz kuće iznosili na Svetog Ivana ili Svetog Stjepana i zaticali ga u štalu za gredu, iznad blaga, gdje je ostajao dok sam ne istrune.

7 Rupa, Cupići i Krivi Put.

48 Za voćke se slama zaticala u selima Veljunu, Žuljevićima, Škopcima i Krivome Putu.

49 U Veljunu, Popićima i Krivome Putu.

50 Ivan Krmpotić Šoparin, Šojatski Dolac.

51 Mara Krmpotić Brndina,Veljun.

52 Eleonora Prpić Lejina, Veljun; te prema podacima iz Upitnice Etnološkog atlasa (UEA, IV, 135, Fd 241/478).

53 Jure Tomljanović Ban, Šolići.

54 Ivan Krmpotić Šoparin, Šojatski Dolac; Mara Krmpotić Brndina, Mirko Prpić Cungo, Senj.

55 Nekoliko kazivača u Veljunu nije potvrdilo unošenje jarma u kuću na Badnjak (Eleonora Prpić Lejina, Ivka Krmpotić Grabarova, Mara Tomljanović Isanova). Jaram nisu u kuću unosili u Cupićima, Šolićima, Žuljevićima i Mrzlome Dolu. Unošenje hamova za konja spomenuo je jedino Ivan Krmpotić Škobac, Škopci. Podaci iz Upitnice Etnološkog atlasa nisu potvrdili ovu pojavu. (UEA, IV, 135, Fd 241/478)

56 Ante Krmpotić Škobac, Škopci.

57 Milan Prpić Markin, Veljun.

58 Od njemačkog schlingen što znači vesti, a šlingeraj je vezivo, vez i čipka. (Klaić 1986:1298)

$59 \mathrm{Na}$ istraživanom području nije zabilježen poseban naziv za kruh koji se pripremao za Božić.

60 Nevenka Krmpotić Aneličina, Veljun; Milan Krmpotić Zekonja, Veljun; Milan i Milka Prpić Markini, Veljun; Ante Krmpotić Škobac, Veljun; Ivica Vukelić, Cupići; Ivanka Krmpotić Grabarova, Veljun; Mara Tomljanović Isanova, Veljun. Jedino su Marko Pavelić Mijatin, Žuljevići i Ivan Krmpotić Šoparin, Veljun/Škopci, naveli da bršljan beru sa stabala u svojoj bližoj okolini, odnosno na području Krivoga Puta. 
Bršljan su, u Veljunu, stavljali u štalu protiv vještica, coprnja ${ }^{61}$ zatim da ne bi zmija ušla u štalu, ${ }^{62}$ te da bi krave davale više mlijeka, a iz istog razloga su im bršljan vezali za rog. Žene su, kada se spremala tuča, uzele taj bršljan iz štale i vani ga zapalile, vjerujući da će tako tuča prije prestati. ${ }^{63}$ Danas u ovim selima malo ljudi drži stoku, pa tako većina više ne stavlja bršljan u štale. U Veljunu ${ }^{64}$ i Šojatskom Dolcu ${ }^{65}$ bršljan su stavljali i na voćke.

\subsubsection{Kićenje bora}

$\mathrm{O}$ sim pšenice i bršljana, u kući se nalazio i bor, stablo jele ili smreke, koje su kitili na Badnjak. Borove su počeli kititi u razdoblju prije Drugoga svjetskog rata, ${ }^{66}$ bombonima, jabukama, orasima, lješnjacima, ${ }^{67}$ raznobojnim krep papirom, obojenim šiškama (češerima), sušenim ružicama, a na vrh bora stavljali su jabuku koja je bila simbol mira, dobrote, ljubavi, ili paunovo pero koje je značilo ponos, a nabavljali su ga u Lici i Slavoniji. ${ }^{68}$ Oko bora stavljala se pšenica, svete sličice, čestitke i slični predmeti. Krajem pedesetih i početkom šezdesetih godina dvadesetog stoljeća, pojavile su se kuglice za kićenje koje su s vremenom i prevladale. ${ }^{69}$ Bor je bio okićen do Sveta tri kralja, kada se stavljao na ognjište da sagori, ${ }^{70}$ ili bi se sasjekao i bacio. ${ }^{71}$

\subsubsection{Ponoćka}

Ta polnoćku su ljudi odlazili oko deset sati navečer u crkvu u Podbilu ili Vratniku, gdje se plesalo i 1 pjevalo prije i nakon mise. Do povratka s polnoćke, cijeli dan tijekom Badnjaka, postilo se. Hrana koju su pripravljali za badnju večer najčešće je bila grah i krumpir na salatu, kuhana jaja, te falši (lažni) bakalar od kuhanog krumpira, dok su tek imućniji kupovali i pripremali bakalar. ${ }^{72}$

\subsection{BOŽıć}

Ta Badnjak se pripremala i hrana za Božić koja se jela nakon povratka s polnoćke, kada prestaje post. 1 Tipična jela koja su se pripremala za Božić bila su: kiselo zelje i meso, a imućniji su jeli i: sarmu, juhu, kuhanu ili pečenu kokoš, odojak, pečeno meso i krvavice. ${ }^{73}$ Pekli su se kolači od jabuke, sira, pe-

${ }^{61}$ Milan i Milka Prpić Markini, Veljun.

62 Ivan Krmpotić Šoparin, Veljun.

63 Mara Krmpotić Brndina, Veljun; Mile Prpić Popić, Mrzli Dol, koji je to zadnji puta vidio tridesetih godina 20. stoljeća, ali nije znao objasniti zašto se bršljan palio.

64 Ivanka Krmpotić Grabarova, Veljun

65 Jure Tomljanović Ban i Ivan Krmpotić Šoparin, Šojatski Dolac

${ }^{66}$ Ivan i Anka Krmpotić Bokulić, Veljun; Milan Krmpotić Zekonja, Veljun; Anka Vukelić Matićeva, Rupe; Ivan Krmpotić Šoparin, Škopci; Mile Prpić Popić, Popići; Mirko Prpić Cungo, Krivi Put. Tijekom terenskog istraživanja teme godišnjih običaja nisu zabilježena sjećanja kazivača o kićenju kuće zelenilom, osim ukrašavanja stola pšenicom i bršljanom. Ukrašavanja bora većina kazivača sjeća se još iz svog djetinjatva, najčešće 30-tih i 40-tih godina 20. stoljeća.

67 Kićenje bora ovim plodovima navodi se i u Upitnici Etnološkog atlasa (UEA, IV, 135, Fd 241/478).

68 Eleonora Prpić Lejina, Veljun

69 Jure Tomljanović Ban, Šolići.

70 Milan Krmpotić Zekonja, Veljun.

71 Jure Tomljanović Ban, Šolići.

72 Eleonoro Prpić Lejina, Veljun

73 Eleonoro Prpić Lejina, Veljun; Anka Vukelić Matićeva, Rupe; Milan Krmpotić Zekonja, Veljun; Mirko Prpić Cungo, Krivi Put; Jadranka Tomljanović, Veljun; Mile Prpić Popić, Mrzli Dol; Ivan Krmpotić Škobac, Veljun; Milan i Milka Prpić Markini, Veljun. 
kmeza, orahnjače, ali najviše suhi keksi koji su, pomoću čaše, ${ }^{74}$ oblikovani u kružne oblike, iz tijesta. Na Badnjak su pekli i božićni kruh koji su stavljali na stol. Taj kruh pekao se prvotno pod pekom, a nestankom otvorenih ognjišta, u pećnici. Božićni kruh bio je sladak, s bogatijim i kaloričnijim sastojcima nego kruh koji se jeo svakoga dana. U tijesto za božićni kruh žene su stavljale mast ili putar, šećer, grožđice ili suhe smokve, jaja i mlijeko. ${ }^{75}$ U Šojatskom Dolcu u tijesto su prije pečenja žene zabadale kuhana jaja u ljusci i tako ga stavljale peći pod peku ili u pećnicu. ${ }^{76}$ Kruh se nije pretjerano ukrašavao, ali su žene ipak prije pečenja nožem urezivale znak križa ili bi križ izradile od tijesta i stavile ga na kruh. ${ }^{77}$ Kruh je najčešće bio jednostavnog kružnog oblika s rupom u sredini ili izrađen poput pletenice, ali isto okrugao - baškot. ${ }^{78}$ U Veljunu se malo božićnog kruha nakon Svetog Stjepana davalo blagu. ${ }^{79}$

Područje Krivoga Puta tamošnje stanovništvo uglavnom poima kao vrlo siromašno. Između ostalog, ističu svakodnevno siromaštvo u hrani. Obilje u hrani i na Badnjak i na Božić bilo je izuzetak, ali se uvijek jelo obilnije i bolje nego inače. To se može zaključiti i prema sjećanjima ljudi o iščekivanju povratka $s$ polnoćke kada se, nakon molitve, moglo početi jesti, mrsiti. Najčešće se jela ćeladija, hladetina.

Na dan Božića, bitna sastavnica proslavljanja je zajedničko blagovanje kada se neposredno prije gozbe pali svijeća i moli. Te postupke obično vrši najstariji član obitelji, domaćin kuće. Na području Krivoga Puta, svijeću su palili prije ručka, te je najstariji član počeo moliti, a za njim i ostali članovi obitelji. Najčešće se molilo Oče naš, Zdravo Marijo, te za zdravlje i za duše pokojnika ${ }^{80}$ Nakon ručka ista osoba gasila je svijeću komadom kruha, prethodno namočenim u vino, ili kapanjem vina iz žlice, a u Rupi i Šolićima svijeću su gasila djeca.

Raširena su vjerovanja vezana uz dim svijeće. Naime kada se svijeća ugasila vinom, pratilo se prema kome će dim krenuti, te se vjerovalo da će ta osoba iduće godine umrijeti ili da će se udati, što je rjeđe rašireno vjerovanje. ${ }^{81} \mathrm{U}$ Veljunu su ljudi vjerovali da ukoliko dim krene prema curi ili dečku udat će se, odnosno oženiti, a ako dim krene uvis, tada će godina biti rodna; ako se dim spusti, umrijet će osoba prema kojoj je dim krenuo. Ukoliko je dim otišao prema djetetu, majka bi rekla: Neće tebe, mene će to doći. ${ }^{82}$ Vjerovanja vezana uz dim svijeće uglavnom su bila raširena među starijom generacijom, rođenom uglavnom početkom 20. stoljeća. Krivopućani rođeni četrdesetih godina 20. stoljeća, dim svijeće često doživljavaju na šaljiv način, bilo da je riječ o udaji ili smrti. Na čitavom području Krivoga Puta, ljudi se živo sjećaju vjerovanja vezanih uz dim svijeće, te ih rado prenose svojim nasljednicima. No, danas se to vjerovanje doživljava isključivo na šaljiv način, ako se uopće i obrati pažnja na to kuda ide dim svijeće. ${ }^{83}$ $\mathrm{Na}$ ovom se primjeru zanimljivo pokazuje kako se pojedini običaji zadržavaju, ali im se stara značenja gube ili mijenjaju kroz vrijeme, tj. nadomještaju ih nova značenja.

$\mathrm{Na}$ Božić se odlazilo čestitati po kućama. Poželjno je bilo da prva osoba koja u nekoj kući čestita Božić bude muško jer muško plodi, žena rodi ${ }^{84}$ Najčešće je to bilo muško dijete. U tom slučaju ljudi su

74 Ivanka Krmpotić Grabarova, Veljun; Ivan Krmpotić Bokulić, Veljun.

75 Nevenka Krmpotić Aneličina, Veljun; Ivan Krmpotić Škobac, Veljun; Mara Tomljanović Isanova, Krivi Put; Ana Vukelić Matićeva; Rupe; Ivan Krmpotić Šoparin, Šojatski Dolac; Anka Krmpotić, Veljun; Ante Krmpotić Škobac, Veljun; Ivan Krmpotić Bokulić, Veljun.

76 Ivan Krmpotić Šoparin, Šojatski Dolac.

77 Ante Krmpotić Škobac, Veljun; Marko Pavelić Mijatin, Žuljevići; Mara Tomljanović Isanova, Krivi Put.

78 Milan Prpić Markini, Veljun

79 Milka i Milan Prpić Markini, Veljun.

80 Ivan Krmpotić Šoparin, Šojatski Dolac.

81 Gatanje o udaji prema dimu božićne svijeće naveli su jedino Milan i Milka Prpić Markinovi iz Veljuna.

82 Ivan Krmpotić Šoparin, Šojatski Dolac.

83 Milan Prpić Markini, Veljun; Mara Krmpotić Brndina, Veljun; Ante Krmpotić Škobac, Veljun; Eleonora Prpić Lejina, Veljun; Anka Vukelić Matićeva, Rupe; Jure Tomljanović Ban, Šolići; Ivanka Krmpotić Grabarova, Veljun; Marko Pavelić Mijatin, Žuljevići; Ivan Krmpotić Šoparin, Šojatski Dolac; Mile Prpić Popić, Mrzli Dol; Mirko Prpić Cungo, Krivi Put; Mara Tomljanović Isanova, Krivi Put; Jadranka Tomljanović, Veljun.

84 Milan Prpić Markini, Veljun. 
vjerovali da će godina biti rodnija, odnosno ako se krava teli.bit (će) muško tele, ako se ovca janji da je sretno da će biti muško, ako je žena za rodit da će biti muško". ${ }^{85}$ U Veljunu je zabilježeno vjerovanje prema kojem nije bilo dobro doći nekome čestitati Božić bos jer bi tada konjima otpale potkove. ${ }^{86}$ Pri ulasku čestitar je rekao:... Hvaljen Isus i Marija, sretan vam Božić.. . rodila p̌senica bjelica, u kućici muška dječica! ${ }^{87}$ Kada je čestitar, za kojeg nisu koristili poseban naziv, došao i zaželio sretan Božić, ukućani su ga počastili pićem, kolačima i svime što imaju pripremljeno za blagdane. Bilo je slučajeva da žena dođe prva čestitati Božić i da je ukućani prime i ugoste jednako kao i muškog čestitara, ali je bilo slučajeva kada je ipak bilo razlike u prijemu, te su tada domaćini bili manje gostoljubivi. ${ }^{88}$ Bez obzira i na današnja tumačenja prema kojima nije bitno tko će prvi čestitati Božić, i kazivanja ljudi kako ne vjeruju da im to utječe na uspjeh godine, ipak muškarci odlaze prvi čestitati Božić ili telefonski zovu, odnosno pošalju muško dijete da čestita. Razlika je u tome da danas čestitar ne čestita pomoću formula kojima se izražava želja za muškim pomlatkom, već koristi „običnije“, ustaljene fraze poput: "Sretan Božić i Nova godina“ i druge slične, danas sveprisutne kako u pisanom, tako i usmenom čestitanju.

\subsection{DANI IZA BOŽIĆA}

Drvi i drugi dan iza Božića spomendani su svetog Stjepana, Stipanje, i svetog Ivana, Ivanje, a obilježeni 1 su spremanjem kuće: iznošenjem slame, pšenice, bršljana i mrvica božićnog kruha. Stanovnici Krivog Puta tim su radnjama tijekom ovih dana željeli osigurati obilje i zaštitu stoci i voćkama u narednoj godini. ${ }^{89}$

Na blagdan Nevine dječice, Mladence, treći dan iza Božića jedna osoba iz kuće, najčešće mama ili baka, ${ }^{90}$ a mogao je to biti i čovjek iz sela, ${ }^{91}$ obilazi kuće i šibom od liske, bukovine ili drina, tuče djecu i mladež, osobito mlade snaše. Ukućani su tu osobu častili pićem i jelom. Na području Krivoga Puta šibanje na Mladence tumačilo se i opravdavalo poticanjem boljega rasta i napredovanja djece. ${ }^{92}$

\subsection{NOVA GODINA}

$\mathrm{N}$ ova godina je obilježavana i slavljena u gostionicama i društvenim domovima u Krivom Putu, ${ }^{93}$ gdje su proslave bile intenzivnije nakon Drugoga svjetskog rata, sve do osamdesetih godina 20. stoljeća. ${ }^{94}$ $\mathrm{Na}$ proslavama su se okupljali i mlađi i stariji. Na Staru godinu, prije proslave u gostionicama, održavana

85 Milan Krmpotić Zekonja, Veljun.

86 Ante Krmpotić Škobac, Škopci.

87 Ivan i Anka Krmpotić Bokulić, Veljun.

88 Mile Prpić Markini, Veljun; Eleonora Prpić Lejina, Veljun; Mirko Prpić Cungo, Krivi Put.

89 Nevenka Krmpotić Aneličina, Veljun; Ivan Krmpotić Bokulić, Veljun; Milan Krmpotić Zekonja, Veljun; Milan Prpić Markini, Veljun; Ante Krmpotić Škobac, Veljun; Eleonora Prpić Lejina, Veljun; Ivanka Krmpotić Grabarova, Veljun; Marko Pavelić Mijatin, Žuljevići, Podbilo; Ivan Krmpotić Šoparin, Veljun; Mile Prpić Popić, Popići.

90 Mile Prpić Popić, Mrzli Dol; Tomo i Ana Špalj Cucini, Krivi Put; Zlata Tomljanović Pešina i Višnja Novoselnik, Senj.

${ }^{11}$ Milan Krmpotić Zekonja, Ive Krmpotić Pićica, te Milan i Milka Prpić Markini iz Veljuna naveli su da je selom obilazio Mirko Krmpotić.

92 Tome i Ana Špalj Cucini, Krivi Put.

93 Prema riječima Milana Krmpotića Zekonje i Ive Krmpotića Pićice u Krivome Putu su bile tri gostionice, a Zlata Tomljanović Pešina rekla je da je bilo i dva doma (domovi su izgrađeni 50-tih godina 20. stoljeća).

94 Proslavu Nove godine spominjali su mi vrlo šturo i kazivači rođeni dvadesetih godina 20. stoljeća, a podaci su se uglavnom odnosili na proslave četrdesetih godine 20. stoljeća. Podaci u tekstu odnose se uglavnom na razdoblje iza Drugoga svjetskog rata kada je proslava Nove godine postala učestalija. Kako za razdoblje prije Drugog svjetskog rata nisu dobiveni podaci, proslavu Nove godine u ranijim razdobljima treba dodatno ispitati tijekom narednih istraživanja ove teme. 
je misa u crkvi u Podbilu. U ranijim razdobljima, ${ }^{95}$ na proslavama, se svirala cintara, usna harmonika, a zatim su se pojavile tamburice, dangubice iz Kutareva, i harmonike. ${ }^{96}$ Tamburicu su svirali trgovac Pešo, ${ }^{97}$ Pere Prpić Nikoličin iz Francikovca, te Vinko Lucin. Uz svirače, bio je i pjevač iz Senjske Drage. ${ }^{98}$ Hrane na proslavama nije bilo u većim količinama, ali je zato pića bilo u izobilju. Za razliku od Badnjaka i Božića koji su se proslavljali u obiteljskom krugu, Nova godina dočekivala se i obilježavala u krugu prijatelja. To je bila prilika da se nakon dužeg vremena vide ljudi koji su iz ovih sela trajno iselili u Senj ili Rijeku. ${ }^{99}$

\subsection{SVETA TRI KRALJA}

Ta Sveta tri kralja završava božićni ciklus te započinje pokladni. Taj dan je bio važan gotovo koliko i 1 sam Božić, ali se obilježavao skromnije, molitvom i odlaskom u crkvu. Oko blagdana Sveta tri kralja dolazio je svećenik blagosloviti kuću, a blagoslov mu se plaćao novcem ili mesnim proizvodima. ${ }^{100}$ Skidali su se ukrasi s bora, a bor se bacao ili spaljivao na ognjištu, ali bez posebnog tumačenja i simboličkog značenja. ${ }^{101} \mathrm{Na}$ dan Sveta tri kralja poznato je gatanje o udaji, prema kojem djevojka na taj dan posti pojevši tri zrna pšenice i popivši napršnjak vode da bi tu noć u snu vidjela dečka za kojeg će se udati. ${ }^{102}$ Rašireno je i vjerovanje o pronalasku zlatnog prstena, prema kojem su djevojke u razdoblju od Božića do Sveta tri kralja trebale svakodnevno prati suđe da bi pronašle taj prsten. ${ }^{103}$

\subsection{KONTINUITET POJEDINIH ELEMENATA BOŽIĆNIH OBIČAJA}

$\mathrm{B}$ ez obzira koliko su se običaji i uvjeti proslave Božića promijenili u današnjem vremenu u odnosu na ranija razdoblja, kako općenito tako i na području Krivoga Puta, može se primijetiti da su se do današnjih dana očuvali pojedini tradicijski elementi. Neki običaji napušteni su iz praktičnih razloga, poput paljenja panja badnjaka i unošenja slame u kuću. Ipak, potvrđeno je kako ovi običaji žive u sjećanjima lokalnog stanovništva i prenose se usmeno na mlađe generacije kao dio tradicijskog nasljeđa. U Senju pojedinci još i danas, unoseći za Božić slamu u kuću, na jedan dan, pokušavaju djeci dočarati „nekadašnje“ obilježavanje Božića, iz svojeg djetinjstva. ${ }^{104}$ Do danas su se očuvali i elementi za koje se vjerovalo da osiguravaju obilje u idućoj godini, primjerice, do danas raširen običaj sijanja pšenice na Svetu Luciju. Većinom se to čini kao i nekad - pšenica se sije u onoliko posudica koliko je osoba u kući. Oko božićnoga kruha i danas većina Krivopućana, bez razlike bili u Krivome Putu ili u Senju, stavlja bršljan. Uglavnom se na selu i danas ne kupuje kruh za Božić, već se peče božićni slatki kruh. U Senju se ipak kruh za Božić pretežito kupuje, iako i tu ima iznimaka. ${ }^{105}$ Svijeća se i danas stavlja u posudu napunjenu sjemenom pše-

95 Prilikom terenskog istraživanja nije precizirano razdoblje na koje se odnosi ova vremenska odrednica.

96 O istim i sličnim instrumentima koji su bili zastupljeni na svadbama, vidi također u prilogu Lucije Čurić o upoznavanju mladih u knjizi o svadbenim običajima Krivopučana (u tisku), kao i o drvenim predmetima koje su izrađivali majstori iz Kutereva u prilogu Tihane Rubić o tradicijskom trgovanju i sajmovima u prvom svesku Monografije, str. 323-352.

97 Suprug kazivačice Zlate Tomljanović Pešine.

98 Prilikom terenskog istraživanja nisu prikupljeni podaci o točnim imenima i prezimenima svirača i pjevača.

99 O iseljavanju u obližnje veće gradove vidi više u prilogu o migracijama autorice Marijete Rajković u prvom svesku Monografije, str. 80-85.

100 Ako pak u neku kuću ne bi došao na sam dan Sveta tri kralja, to je bilo iz praktičnih razloga - nije mogao obići cijelo područje Župe u jednom danu.

101 Jure Tomljanović Ban, Šolići.

102 Milka i Milan Prpić Markini iz Veljuna. Milki Prpić Markinoj o ovom gatanju o udaji ispričala je njezina majka, a kazivačica ga sama nije prakticirala. Vidi više o gatanjima u prilogu autorice Sanje Lončar, u knjizi o svadbenim običajima Krivopučana (u tisku).

103 Milan Krmpotić Zekonja, Veljun.

104 Mirko Prpić Cungo, Krivi Put.

105 Eleonora Prpić Lejina i Ivka Krmpotić Grabarova. 
nice ili ječma, a ukućani je nakon večere gase vinom i gledaju kuda će dim krenuti, ali danas taj dim promatraju kroz šalu. Zadržao se i običaj da muška osoba prva čestita Božić, ali se izgubilo prvotno značenje ovog postupka koji je trebao utjecati na plodnost u predstojećoj godini, no i danas se smatra - srećom. To se može protumačiti činjenicom da većina ljudi, pogotovo u urbanim sredinama, više nije čvrsto vezana uz seoske načine privređivanja, te im značenje agrarnog obilja u predstojećoj godini nije relevantno. Forma običaja je zadržana, ali je značenje zaboravljeno.

Danas veći broj elemenata božićnog ciklusa običaja ima izmijenjeno značenje, kako na području Krivoga Puta tako i u urbanim sredinama (Senju), te su više rezultat nostalgije i svjesne rekonstrukcije „nekadašnjeg" načina života, nego vjerovanja u mogućnosti utjecanja na obilje i urod u nadolazećoj godini.

\section{USKRSNI OBIČAJI106}

\subsection{KORIZMA}

Takon pokladnog razdoblja, ${ }^{107}$ koje završava Pepelnicom, započinje korizmeno razdoblje obilježeno 1 postom, uzdržavanjem od obilnijeg jela i naglašenom pobožnošću, a sve te radnje predstavljaju simboličko i fizičko čišćenje od prethodnog razdoblja. (Čapo Žmegač 1997:29-30) Tako se na području Krivoga Puta u korizmenom razdoblju nije vjenčavalo, što se objašnjava praktičnim razlogom da ne bi proljetna mlada došla u praznu kuću, zato mora doći u jesen kad je kuća puna (hrane op.a.). ${ }^{108}$

Korizmom započinje uskrsno razdoblje koje završava tjedan dana nakon Uskrsa. Svi datumi ovoga perioda, kao uostalom i završetak pokladnog perioda, ovisni su o datumu Uskrsa koji je pomičan, a slavi se prve nedjelje nakon proljetnog uštapa.

\subsection{CVJETNICA}

$\mathrm{N}_{\mathrm{u}}^{\mathrm{a}}$ a Cvjetnicu, tjedan dana prije Uskrsne nedjelje, djevojke i mladići su u crkvu Majke Božje Snježne u Podbilu nosili na blagoslov grančice drina (drijenak), koje su sami ubrali u blizini vlastite kuće, i masline, koje su nabavljali u Senju ${ }^{109}$. Blagoslovljene grančice vrlo često su na Jurjevo koristili u radnjama koje su blagu trebale osigurati zdravlje i spriječiti mogući ugriz zmije. ${ }^{110}$ Maslinova grančica, na području Krivoga Puta, najčešće se čuvala u kući, zataknuta za pojedine predmete, prozor, okvire slika i ogledala, a kada se sasušila ljudi su je bacali u vatru. ${ }^{111}$ Drenak se zaticao za gredu u štali i tamo je ostajao dok se ne osuši i dok sam ne otpadne. ${ }^{112}$ Danas je magijska uloga maslinove i drinove grančice uglavnom nestala iz prakse, odnosno zabilježena je jedino u sjećanjima ljudi na ovom području, na nekadašnji postupak zaticanja drinove grančice. Postupak se vjerojatno izgubio u praksi onda kada je i uzgoj blaga postupno isčezao na ovom području (oko sedamdesetih godina 20. stoljeća), zbog iseljavanja stanovništva.

$\mathrm{Na}$ Cvjetnicu su do sredine 20. stoljeća stariji ljudi blagoslovljenim grančicama udarali djecu i tim udarcima pravili križ. ${ }^{113}$ Blagoslovljene grančice koristile su se i prilikom presađivanja povrća, te su se

106 Terenskim istraživanjem i ovim radom nastojalo se prikazati godišnje običaje na području Krivoga Puta, a zbog širine same teme za pojedine dijelove poput Uskrsa, posebice korizmenog razdoblja, prikupljena je manja količina podataka, te je iste potrebno detaljnije ispitati tijekom budućih terenskih istraživanja.

107 O pokladnim običajima vidi više u prilogu Nevene Škrbić-Alempijević i Aleksandre Vlatković u ovom svesku Monografije.

108 Mirko Prpić Cungo, Krivi Put.

109 Nevenka Krmpotić Aneličina, Veljun; Milan Krmpotić Zekonja, Vlejun; Ivanka Krmpotić Grabarova, Veljun; Marko Pavelić Mijatin, Žuljevići; Ivan Krmpotić Šoparin, Veljun; Mile Prpić Popić, Popići; Mirko Prpić Cungo, Krivi Put.

110 Mile Prpić Popić, Popići; Mara Krmpotić Brndina, Veljun.

111 Ivanka Krmpotić Grabarova, Veljun.

112 Milan Krmpotić Zekonja, Veljun; Ivan Krmpotić Šoparin, Veljun; Mile Prpić Popić, Popići.

113 Jadranka Tomljanović iz Veljuna sjeća se kako ju je grančicom simbolički znala ošinuti njezina baka, objašnjenjem da će djeca na taj način biti dobrog vladanja, a danas ona simbolički blagoslovljenom maslinovom grančicom lupne svoju djecu. 
tada prekrižene stavljale u zemlju. ${ }^{114} \mathrm{U}$ Veljunu se blagoslov (blagoslovljena grančica, sol i voda) stavljao u zemlju kada se sijalo i sadilo. ${ }^{115}$ Malo blagoslovljene hrane i maslinovih grančica davalo se blagu pojesti, vjerujući da će mu se time osigurati zdravlje u idućoj godini. ${ }^{116}$

Grančica masline i danas se nosi na blagoslov u crkvu u Podbilu, dok se drijenak nosi rjeđe. Većina ljudi i danas ostavlja maslinovu grančicu zataknutu u kući, dok samo poneki blagoslov zatiču i u štali. ${ }^{117}$ Iako blagoslovljena grančica sve manje u svijesti ljudi ima zaštitnu moć koja joj je nekada pripisivana i dalje je prisutna u običajima uskrsnoga ciklusa.

\subsection{VELIKI TJEDAN}

$\mathrm{V}$

eliki je Petak ponajprije bio obilježen strogim suzdržavanjem od rada i jela, te nizom „zabrana“; na Veliki petak nije bilo dozvoljeno raditi na zemlji te su se konjima skidale potkove kako i oni ne bi rovali i kopali zemlju, a iz istog su se razloga i kokoši držale zatvorenima. ${ }^{118} \mathrm{Na}$ Veliki petak se nije smjelo jesti meso i druga masna hrana. Postojala su vjerovanja vezana uz vrijeme i zemlju, te se vjerovalo da kad na Veliki petak pada kiša, onda ne valja, zemlja puca preko lita. ${ }^{19} \mathrm{Na}$ taj su se dan bojala i jaja lupinama crvenog luka prokuhanim u vodi, a ponekad su ih ukrašavali travom i lišćem, a starije generacije znale su nešto i napisati na jajetu. ${ }^{120}$

$\mathrm{Na}$ Veliku subotu ljudi su sijali prisad, odnosno presađivali kupus.

\subsection{USKRS}

Ta Uskrs, rano ujutro, nosili su hranu na blagoslov, a najčešće su to činila djeca. ${ }^{121}$ Na blagoslov se 1 nosio kruh koji se nije spravljao od posebnih sastojaka, samo su se ponekad u kruh stavljale grožđice. Zatim se nosila kapula (luk), škanjula (mladi luk), češnjak, žito, malo mlijeka, sol, pršut, kuhana i obojana jaja. U Veljunu su s blagoslovljenom škanjulom ljudi kravama mazali njušku da kravu ne bi ugrizla zmija. ${ }^{122} \mathrm{U}$ istom mjestu zabilježeno je da su ljudi na Uskrs ujutro žvakali blagoslovljenu maslinovu grančicu s malo kruha ili s kolačom i rakijom. Kad su prožvakali, bacili su to u vatru, iz praktičnih razloga jer nisu mogli progutati. ${ }^{123}$ Ipak, ovu radnju ljudi povezuju simbolički i s Isusom kojem su davali žvakati žuhku (gorku) maslinu. ${ }^{124}$

Zabilježena je i igra s uskrsnim jajima koju su igrala djeca udarajući jaje o jaje, tuckaju se.

U ciklusu uskrsnih običaja do danas se zadržao običaj blagoslova i čuvanje maslinove i drinove grančice, ali im se magijsko značenje izgubilo. Dosta ovdje predstavljenih običaja zaboravljeno je, žive u sjećanjima pojedinaca ili se prakticiraju, ali u izmijenjenim oblicima i s novim značenjima. No običaji nisu statične, nepromjenjive pojave, oni se mijenjaju sukladno društvenim i političkim prilikama.

\footnotetext{
114 Mara Tomljanović Isanova, Veljun; Mirko Prpić Cungo, Krivi Put, Tomo i Ana Špalj Cucini, Krivi Put.

115 Milka i Milan Prpić Markini, Veljun.

116 Marko Pavelić Mijatin, Žuljevići.

117 Milan Krmpotić Zekonja i Nevenka Krmpotić Aneličina.

118 Ivan Krmpotić Šoparin, Veljun; Milka Prpić Markina, Veljun.

119 Milka Prpić Markina, Veljun.

120 Kazivači nisu znali reći što se na uskrsna jaja ispisivalo.

121 Milka Prpić Markina, Veljun.

122 Ive Krmpotić Pićica, Veljun.

123 Milka i Milan Prpić Markini, Veljun.

124 Milka i Milan Prpić Markini, Veljun.
} 


\section{JURJEVO}

$\mathrm{N}$

akon Cvjetnice i Uskrsa slijedi Jurjevo (21. travnja), kao početak gospodarske godine ${ }^{125}$ (Gavazzi 1939:41). Na taj dan u većini običaja koriste se grančice blagoslovljene na Cvjetnicu u svrhu zaštite stoke. ${ }^{126} \mathrm{Na}$ Jurjevo ujutro običaj je bio da pri izgonu stoke gazda, gazdarica ili stariji ukućanin, svako govedo ili ovcu udari s blagoslovljenom grančicom ${ }^{127}$ i poškropi blagoslovljenom vodom, a ponegdje su stoci davali i malo blagoslovljene soli. U Veljunu su uvečer, pri vraćanju stoke u štalu, dvije starije žene imale upaljene svijeće između kojih je stoka morala proći u štalu, a na zadnjoj životinji su gasile svijeće. ${ }^{128}$ Vjerovalo se da će se ovim postupkom zaštititi blago od ugriza zmija, groma i drugih nemilosti. Na Jurjevo su blago od coprnja, vještica, zaštitili tako da su cijeli dan bila zatvorena vrata štale. ${ }^{129}$ Također su žene na Jurjevo stavljale blagoslovljenu drijenovu ili maslinovu grančicu na tavu s malo žara, te su to davali stoci njušiti vjerujući da će blago tako zaštiti od zmije. ${ }^{130}$

Vjerovalo se da ako je prozelenila gora prvo nego on (op. Sveti Juraj) dođe...kažu doći će sveti Juraj na zelenom konju. Sve će roditi. Al ako dođe na crnom, bogami sve nam je crno do kraja. ${ }^{131}$ Slično tome je i vjerovanje da predstojeća godina neće biti rodna ako kukavica zakuka na crnu goru, odnosno po zimi dok još nema zelenila u prirodi, prije Jurjeva. ${ }^{132} \mathrm{U}$ ovakve predznake Krivopućani su vjerovali, a neki i danas vjeruju, pa je tako u Veljunu zabilježeno da je ovu godinu...već zimus počela kukati (op. kukavica) i sve je suho. ${ }^{133} \mathrm{Na}$ Jurjevo je također vrlo rasprostranjen običaj da onaj tko ima volove, taj dan ih ne može koristiti za sebe. Tada ih posuđuje drugima, koji nemaju volove, da rade na polju. Ovdje je zabrana prevladana društvenom solidarnošću.

Ukoliko je netko zaspao na Jurjevo, onaj tko se ranije ustao, recitirao mu je:

Pridajen ti sanak na Đurdev danak, Ja leštar kao ptica, a ti lin kao magarica, Pridajen ti sanak na Đurdev danak. ${ }^{134}$

\section{PROLJETNE VATRE}

$\mathrm{O}$ paljenju vatri na području Krivoga Puta postoje sjećanja vezana većinom za prvi svibanj. Te vatre su se počele paliti nakon 1945. godine, u socijalističkom razdoblju, pa sve do osamdesetih godina 20. stoljeća, kada se stanovništvo već počelo intenzivnije iseljavati s područja Krivoga Puta. Prvomajske vatre palile su se na brdima u većini mjesta na ovom području. Jurjevske vatre spominju se samo u Veljunu gdje

125 Tijekom istraživanja na ovom području nisu potvrđene potvrde i sjećanja o proljetnim ophodima (npr. na Jurjevo, Duhove i sl.), a ne potvrđuju ih ni podaci za Krivi Put iz Upitnice Etnološkog atlasa (UEA, IV, 138-139, Fd 241/478).

${ }^{126}$ Ivan Krmpotić Bokulić, Veljun; Ivanka Krmpotić Grabarova, Veljun; Ivan Krmpotić Šoparin, Veljun; Mirko Prpić Cungo, Krivi Put; Jadranka Tomljanović, Veljun;

127 Prema kazivanju Eleonore Prpić Lejine iz Veljuna životinje su po glavi lagano lupili s blagoslovljenom grančicom pri tome čineći križ.

${ }_{128}$ Milan i Milka Prpić Markini, Veljun.

129 Milan Prpić Markini, Veljun;

${ }_{130}$ Ivan Krmpotić Šoparin, Šojatski Dolac; Mara Tomljanović Isanova, Veljun.

131 Milan i Milka Prpić Markini, Veljun.

${ }^{132}$ Ivan Krmpotić Šoparin, Šojatski Dolac. Sličnu priču zabilježila je Petra Kelemen u Senju od Tome Špalja Cucina iz Krivog Puta koji je rekao: "Đurad jaše na zelenu konju, prolistat će šuma i tako".

${ }_{133}$ Milan i Milka Prpić Markini, Veljun.

134 Tomo Špalj Cucin, Krivi Put. 
se kazivači sjećaju da su se večer prije Jurjeva palile vatre oko kojih se okupilo deset do petnaest mlađih ljudi koji su tad plesali kolo, te se valjali po livadi vjerujući da ih nakon toga neće boljeti leđa i križa. ${ }^{135}$ $\mathrm{Na}$ Jurjevo su u Veljunu djeca bosa preskakivala preko vatre, te se vjerovalo da neće imati bradavice i da će općenito biti zdravija. ${ }^{136}$

\section{IVANJE}

Sve do polovice 20. stoljeća, u ljetnom je periodu kazivačima najupečatljiviji bio spomendan svetog IvaOna (Ivanje, 21. lipnja), kada su se na seoskoj livadi, u ranu zoru, sastajale djevojke kako bi plele vijence od bijelih rožica (ivančica). Vijence su bacale zajedno na krov kuća, ili je svaka bacila vijenac na svoju, obiteljsku, kuću. Prema tome gdje je vijenac pao, određivale su kada će se koja udati, odnosno za koliko godina. ${ }^{137}$ U Veljunu je zabilježen običaj da mlađa osoba iz kuće stavi bijele rožice u sito, jednu za svakog ukućana, i sito stavi na krov, vjerujući kako će prvi umrijeti onaj čija ružica prva uvene. ${ }^{138}$ Danas se običaj više ne izvodi u praksi, ${ }^{139}$ ali je zabilježeno sjećanje na nj, te podatak kako su se ivanjski krijesovi, kao zabavan društveni događaj u naseljima na području Krivoga Puta, palili do Drugoga svjetskog rata. ${ }^{140}$

\section{SVETI MARTIN}

Cpomendan svetog Martina (11. studenoga) obilježavao se kao prestanak radova u polju, te su ljudi na $\checkmark$ taj dan unosili jaram u kuću i spremali ga do proljeća. Obzirom da danas malo ljudi obrađuje zemlju, ovaj običaj održao se u sjećanju ljudi, ali i u uzrečici poznatoj na čitavom području Krivoga Puta: Sveti Martin jaram na pod, vole pod pod (na tavan op.a.) ili Sveti Martin pušku na klin, vole pod pod, jaram na pod. ${ }^{141}$

Iznimku predstavlja Mirko Prpić Cungo koji jedini na području Krivoga Puta (zadnjih tridesetak godina) krsti mošt. Grožđe za vino sam ne uzgaja, već kupuje, a pravljenje i krštenje mošta naučio je od svog prijatelja, porijeklom iz Krivoga Puta, a oženjenog u Pitomači, gdje je počeo pripremati i krsti mošt na Svetoga Martina.

Običaj je na ovom području, kojemu nedostaje uzgoj vinove loze, prihvaćen primarno zbog svojih zabavnih karakteristika. ${ }^{142}$ Tom prilikom okupe se prijatelji u nekoj od senjskih konobi, gdje svi međusobno nazdrave s punim čašama, bez posebnih zdravica i blagoslova. Ipak, prisutan je šaljivi ton krštenja mošta, specifičan za područja Hrvatske u kojima je ova praksa uobičajena. (usp. Lozica 1990:152-153) Na ovaj način unesen je novi element u ciklus godišnjih običaja Krivopućana.

\section{ZAKLJUČNA RAZMATRANJA O GODIŠNJIM OBIČAJIMA}

$\mathrm{A}^{\mathrm{k}}$ ko se osvrnemo na građu prikupljenu na području senjskoga zaleđa, uvidjet ćemo da postoje metonimijske prakse u kojima su pučke prakse i vjerovanja s kršćanskim blagdanom vezane jedino vremenom, a to bi bilo: sijanje pšenice za svaku osobu u kući na Svetu Luciju, paljenje panja badnjaka, unošenje jarma u kuću, paljenje i gatanje svijećom u ciklusu božićnih običaja, gatanje o udaji za Ivanje, unošenje

\footnotetext{
135 Milan Krmpotić Zekonja i Mara Krmpotić Brndina, Veljun.

136 Jadranka Tomljanović, iz Senja, sjeća se da joj je baka govorila kako su u njezino vrijeme (prva polovica 20. stoljeća) na Jurjevo palili vatru.

137 Prema kazivanju Milana i Milke Prpić Markini iz Veljun, te Ivana Krmpotića Šoparina iz Škopaca broj godina do udaje određivao se prema rednom broju horizontalne trake na krovu, gdje je vijenac pao.

${ }_{138}$ Milka i Mile Prpić Markin, Veljun.

139 O Ivanjskim vatrama na ovome području vidi u: Pavelić 1973:184.

140 Isti kazivači.

141 Marko Pavelić Mijatin(a), Žuljevići.

${ }_{142}$ Mirko Prpić Cungo, Krivi Put.
} 
jarma u kuću na Svetog Martina i druge slične radnje. Metonimijsko-metaforičkim praksama moglo bi se protumačiti i unošenje slame koja se smatra elementom pretkršćanskog porijekla koji je kristijaniziran, a razlog unošenja povezuje se s time što je Isus rođen na slami. Isto je i s obilaženjem kuća na spomendan Nevine dječice i udaranjem mladih sa šibom od liske, bukovine ili drijena, kao i zabranom kopanja zemlje na Veliki petak.

Metaforičkim praksama mogu se protumačiti i sve radnje kojima se blagoslovima utječe na boljitak, primjerice: davanje pšenice blagu nakon blagoslova na Sveta tri kralja; stavljanje blagoslova na gumno ili miješanje sa sjemenom za sijanje; zaticanje božićne slame za voćke i bršljana s božićnog stola u štalu; te korištenje blagoslovljene maslinove i drinove grančice kojima se na Jurjevo stoka izgonila, ili su se grančice stavljale u zemlju prilikom sadnje nekih drugih biljaka (usp. Belmont 1982; prema Čapo Žmegač 1997:66-67).

Struktura običaja, kao i okolnosti proslave ovih blagdana, promijenili su se tijekom 20. stoljeća (razdoblja koje ovaj prilog obuhvaća). Neki običaji su na području Krivoga Puta napušteni zbog praktičnih razloga, poput paljenja panja badnjaka i unošenja slame u kuću. Do danas su se očuvali tek pojedini elementi iz ranijih razdoblja, a dio ih „živi“ tek u sjećanjima Krivopućana starije životne dobi. U kazivanjima potvrđuju kako vlastita sjećanja na stare običaje prenose mlađim generacijama pripovijedanjem o njima, i to najčešće prigodno, u kontekstu obilježavanja pojedinih blagdana. Pritom podcrtavaju prije svega simboličku važnost običaja. Primjerice, Mirko Prpić Cungo u Senju još i danas na Božić unosi slamu na jedan dan u kuću i tako pokušava djeci dočarati nekadašnju proslavu Božića, kakvu pamti iz djetinjstva. Drugi pak, primjerice, stave malo slame pod kruh. ${ }^{143}$

Do danas su zadržani elementi sadržaja blagdanskoga stola iz prve polovice 20. stoljeća, a za koje se vjerovalo da osiguravaju obilje u idućoj godini; tako je danas raširen običaj sijanja pšenice na Svetu Luciju, te stavljanje bršljana oko božićnoga kruha. Mnogi Krivopućani i danas peku božićni slatki kruh, ali u Senju ga većina ipak kupuje. Svijeća se i danas stavlja u posudu napunjenu zrnjem pšenice ili ječma, a ukućani je nakon večere gase vinom i gledaju kuda će dim krenuti, ali gatanja dimom danas promatraju isključivo u šaljivom tonu.

Održao se i običaj da muška osoba prva čestita Božić. U suvremenom društvu, većina elemenata božićnog ciklusa običaja ima drugo značenje. Provedba pojedinih običajnih praksi više je izraz nostalgije i prizivanje sreće i boljitka u idućoj godini.

U ciklusu uskrsnih običaja do danas se zadržao običaj blagoslova te čuvanje maslinove i drinove grančice, ali im se magijsko značenje izgubilo.

Običaji koji su ovdje predstavljeni, uglavnom se danas ne prakticiraju, ali žive u sjećanjima pojedinaca, ili se prakticiraju u znatno izmijenjenom obliku, te $s$ izmijenjenim značenjem. Uzrok nestanka pojedinih običaja nalazi se dijelom u dekrisitijanizaciji koju je zagovarao socijalistički svjetonazor, ali i u premještanju stanovništva, raspadu lokalnih zajednica, te modernizaciji. Pored toga, običaji nisu statične, nepromjenjive pojave, običaji se mijenjaju u kontekstu promjena društvenopolitičkih i drugih prilika.

\section{LITERATURA I IZVORI:}

ANIĆ, Vladimir (2002): Hrvatski enciklopedijski rječnik. Novi liber: Zagreb.

BELAJ, Vitomir (1998): Hod kroz godinu. Mitska pozadina hrvatskih narodnih običaja i vjerovanja. Golden marketing: Zagreb.

BOGOVIĆ, Mile (2008): Župa Krivi Put. U: Živjeti na Krivom Putu. Etnološko - povijesna monografija o primorskim Bunjevcima, svezak I, ur. M. Černelić, M. Rajković, T. Rubić, FF-press i Gradski muzej Senj, Zagreb, 2008., 69-75.

ČAPO ŽMEGAČ, Jasna (1997): Hrvatski uskrsni običaji. Golden marketing: Zagreb.

143 Milka i Mile Prpić Markini, Veljun. 
ČERNELIĆ, Milana (2006): Bunjevačke studije. FF press: Zagreb.

GAVAZZI, Milovan (1939): Godina dana hrvatskih narodnih običaja. Matica Hrvatska: Zagreb.

GAVAZZI, Milovan (1978): Vrela i sudbine narodnih tradicija. Liber, Zagreb.

LOZICA, Ivan (1990): Izvan teatra, Hrvatsko društvo kazališnih kritičara i teatrologa, Zagreb.

LJUBOVIĆ, Blaženka (2008): Zemljopisni položaj i pregled novije povijesti Krivoga Puta. U: Živjeti na Krivom Putu. Etnološko - povijesna monografija o primorskim Bunjevcima, svezak I, ur. M. Černelić, M. Rajković, T. Rubić, FF-press i Gradski muzej Senj, Zagreb, 2008., 49-68.

PAVELIĆ, Rikard (1973): Bunjevci. Osobna naklada: Zagreb.

RAJKOVIĆ, Marijeta (2008): Pregled suvremenih migracija Krivopućana. U: Živjeti na Krivom Putu. Etnološko - povijesna monografija o primorskim Bunjevcima, svezak I, ur. M. Černelić, M. Rajković, T. Rubić, FF-press i Gradski muzej Senj, Zagreb, 2008., 79-94.

RAJKOVIĆ, Marijeta (2008): Tradicijski i suvremeni lov. U: Živjeti na Krivom Putu. Etnološko - povijesna monografija o primorskim Bunjevcima, svezak I, ur. M. Černelić, M. Rajković, T. Rubić, FF-press i Gradski muzej Senj, Zagreb, 2008., 265-278.

RIHTMAN-AUGUŠTIN, Dunja (1992): Knjiga o Božiću. August Cesarec: Zagreb.

RIHTMAN-AUGUŠTIN, Dunja (2000): Ulice moga grada. Biblioteka XX vek: Beograd.

RUBIĆ, Tihana (2008): Tradicijska trgovina i sajmovi. U: Živjeti na Krivom Putu. Etnološko - povijesna monografija o primorskim Bunjevcima, svezak I, ur. M. Černelić, M. Rajković, T. Rubić, FF-press i Gradski muzej Senj, Zagreb, 2008., 323-352.

ŠARIĆ, Marko (2008): Bunjevci u ranome novom vijeku. Postanak i razvoj jedne predmoderne etnije. U: Živjeti na Krivom Putu. Etnološko - povijesna monografija o primorskim Bunjevcima, svezak I, ur. M. Černelić, M. Rajković, T. Rubić, FF-press i Gradski muzej Senj, Zagreb, 2008., 15-44.

Upitnica Etnološkog atlasa (UEA), Svezak IV; Teme broj: 135. Badnjak (panj, stablo, grana), božićno zelenilo, slama; 136. Čestitanje, polaznik, ophodi i igre u božićno i novogodišnje doba; 138. Proljetni ophodi sa zelenilom i za kišu; 139. Duhovski ophodi i igre; 140. Pisanice, Fd 241/1382 (Krivi Put), Arhiv Odsjeka za etnologiju i kulturnu antropologiju, Filozofski fakultet u Zagrebu.

VLATKOVIĆ, Aleksandra (2003): Odijevanje i tekstilno rukotvorstvo primorskih Bunjevaca. Senjski zbornik, 30:587-682, Senj.

VLATKOVIĆ, Aleksandra (2005): Godišnji običaji primorskih Bunjevaca Krivoga Puta. Senjski zbornik, 32:317-348, Senj. 